\title{
Analisis Kontrastif Konstruksi Kalimat [ka- verba] dalam Bahasa Sunda dengan [-rareru] dalam Bahasa Jepang
}

\author{
Inu Isnaeni Sidiq ${ }^{* 1}$, Agus Suherman ${ }^{\star 2}$,Taufik Ampera ${ }^{3}$ \\ Fakultas IImu Budaya \\ Universitas Padjadjaran \\ inu.isnaeni.sidiq@unpad.ac.id \\ agus.suherman@unpad.ac.id \\ taufik.ampera@unpad.ac.id
}

\begin{abstract}
Abstrak
Bahasa Jepang dan bahasa Sunda memiliki persamaan karakteristik dalam struktur ujaran pasif yang digunakan dalam komunikasi sehari-hari. Salah satunya adalah adanya konstruksi kalimat pasif tak langsung di kedua bahasa tersebut yang diekspresikan melalui konstruksi kalimat [ka-verba] dalam bahasa Sunda dan [rareru] dalam bahasa Jepang. Penelitian ini bertujuan untuk menjelaskan persamaan dan perbedaan kedua konstruksi kalimat pasif tak langsung tersebut agar para pembelajar bahasa Jepang asing, terutama yang menggunakan bahasa Sunda sebagai bahasa Ibunya dapat memahami dengan lebih baik konstruksi kalimat dari kedua bahasa tersebut. Metode yang digunakan dalam penelitian ini adalah metode deskriptif kualitatif dengan menggunakan data yang diperoleh dari korpus bahasa Sunda dan bahasa Jepang. Melalui penelitian ini penulis berhasil menemukan bahwa konstruksi kalimat pasif tak langsung [ka-verba] dan [rareru] hanya menunjukkan makna dan fungsi yang sama saat digunakan untuk mengungkapkan peristiwa yang terjadi dengan sendirinya (jihatsu) dan bentuk dapat (kanoubun). Selain itu, penulis juga menemukan bahwa kedua konstruksi kalimat pasif tersebut dapat juga dibentuk dari kata dasar verba intransitif dan berfungsi sebagai tuturan pasif impersonal

Kata kunci: pasif tak langsung; non-volitonal ; jihatsu;kanoubun; pasif impersonal
\end{abstract}




\section{Abstract}

Basa Sunda and Japanese language have so many similiratity in terms of passive expressions. Both language recognize direct passive utterance and indirect passive utterance. This paper analyzes indirect passive construction of basa Sunda and contrast them to similar construction in Japanese. This paper show that from four of the basa Sunda's indirect passive construction functions, only two of them comply to the Japanese indirect passive construction semantically. These functions are spontaneus clause (jihatsu) and potential clause (kanou). Despite of the semantic similarity, this paper also show that these type of indirect passive can be constructed from intransitive verbs in both language.

Keyword : indirect passive; jihatsu;kanoubun;impersonal passive

\section{Pendahuluan}

Bahasa Sunda merupakan bahasa daerah kedua terbesar di Indonesia dengan jumlah penutur sebanyak kurang lebih tiga juta orang. Namun demikian, bahasa yang termasuk ke dalam cabang bahasa proto melayu dari keluarga bahasa asutronesia ini belum mendapatkan perhatian yang begitu banyak sebagai objek penelitian linguistik. Hal ini terbukti dengan masih sedikitnya referensi tertulis baik berupa buku maupun artikel jurnal yang membahas karakteristik linguistik bahasa Ini secara mendalam termasuk di dalamnya adalah karakter konstruksi tuturan pasif.

Berbeda dengan bahasa - bahasa Eropa yang seringkali menjadi objek penelitian linguistik umum yang hanya mengenal jenis pasif langsung (selanjutnya disebut PL), bahasa Sunda juga memiliki konstruksi khusus untuk mengungkapkan sebuah peristiwa di mana subjek dalam tuturan tersebut mengalami kerugian baik fisik atau pun psikis dari terjadinya sebuah peristiwa yang secara langsung tidak terkait ataupun tertuju kepada subjek tersebut. Konstruksi seperti ini disebut sebagai tuturan pasif tak langsung (selanjutnya disebut PTL) dan ditandai dengan konstruksi predikat [ka-verba]. Mari kita lihat contoh berikut ini :

(1). Si Ujang Katenggeul ku si Budi.

Ujang ka-pukul oleh Budi

"Ujang terpukul oleh Budi"

(2) Rahmad kaheumpikan sapedah.

Rahmad ka - ngaheumpikan sapedah

“ Rahmad terhimpit sepeda." 
Pada data (1), predikat [ka- tenggeul] menunjukkan makna bahwa Budi yang menjadi pelaku dari pemukulan sebenarnya menujukan tindakannya terhadap orang lain, tetapi karena suatu alasan pukulan tersebut secara tidak sengaja mengenai Ujang yang kebetulan berada di lokasi kejadian tersebut. Kemudian pada data (2) kita juga bisa memahami bahwa peristiwa tersebut terjadi secara kebetulan tetapi dampaknya menimbulkan kerugian secara fisik kepada subjek kalimat, dalam hal ini Rahmad. Akan tetapi dalam percakapan sehari - hari, ternya konstruksi [ka-verba] ini tidak hanya digunakan untuk menunjukkan PTL, tetapi juga untuk menunjukkan makna potensial (kanou) seperti pada data (3) dan juga spontan (jihatsu)seperti pada data (4) berikut ini :

(3). Tulisan leutik kitu mah moal kabaca atuh!

Tulisan kecil seperti itu tidak akan ka-maca dong

"(Kalau) tulisan(nya kecil seperti itu tidak akan terbaca dong."

(4). Hate nu tadina liwung, karasa reeus.

Hati yang tadinya galau ka- merasa bahagia

" Hati yang tadinya galau , menjadi bahagia( tenang)."

Apabila kita cermati, verba dasar dari predikat kalimat (1), (2), dan (3) adalah verba transitif, sedangkan predikat kalimat (4) berasal dari verba dasar intransitif. Namun demikian, hal ini tidak berarti bahwa semua verba intransitif dapat bergabung dengan awalan [ka-], sehingga perlu ditelaah lebih lanjut terkait dengan batasan - batasan verba intransitif apa saja yang dapat bergabung dengan awalan [ka-] dan menjadi predikat pada konstruksi tersebut. Akan tetapi, pada penelitian kali ini penulis tidak akan membahas permasalahan tersebut, tetapi memfokuskan sisi makna dan struktur kalimat terutama pada jenis nomina yang menempati posisi subjek serta mengkontrastifkannya dengan tuturan bermakna serupa dalam bahasa Jepang sehingga dapat ditemukan persamaan dan perbedaan karakteristik di antara kedua bahasa tersebut. Adapun dasar pemilihan bahasa Jepang sebagai pembanding adalah karena bahasa Jepang dikenal memiliki dua jenis tuturan pasif serupa yaitu PL dan PTL. Selain itu, penulis berharap kajian - kajian terdahulu terkait tuturan PL dan PTL dalam bahasa Jepang juga telah banyak dilakukan juga dapat menjadi referensi untuk mengidentifikasi karakteristik - karakteristik tuturan serupa dalam bahasa Sunda yang notabene masih perlu ditelaah lebih dalam.

Atas dasar itulah, penulis memutuskan untuk melakukan penelitian dengan tema Analisis Kontrastif Konstruksi Kalimat [ka-verba] dalam 
Bahasa Sunda dengan [-rareru] dalam Bahasa Jepang”.

II. Metode Penelitian

Metode yang digunakan dalam penelitian ini adalah metode deskriptif. Metode penelitian deskriptif adalah metode yang bertujuan membuat deskripsi, yaitu membuat gambaran, lukisan secara sistematis, faktual dan akurat mengenai data, sifat-sifat serta hubungan fenomenafenomena yang diteliti. Metode ini dikatakan pula sebagai pencarian data dengan interprestasi yang tepat (Djajasudarma, 2010:9).

Adapun teknik pengumpulan data dilakukan dengan langkahlangkah sebagai berikut, yakni studi kepustakaan, klasifikasi, analisis, dan terakhir simpulan

\section{Pembahasan}

Teramura (1982:215) menyatakan bahwa pada dasarnya, dalam bahasa Jepang dikenal dua jenis ujaran pasif, yaitu pasif langsung dan tak langsung . Mari kita amati contoh (5) dan (6) berikut.

(5). 花子は太郎に吒かれた。

Hanako NOM Taro By tampar-PASS-PST

"Hanako ditampar oleh Taro."

(6). 僕は彼女に泣かれた。

Aku (laki-laki) NOM dia (perempuan) By tangis - PASS-PST "Aku (laki-laki) ditangis(i) olehnya (perempuan)?."

Walaupun ciri secara morfologis verba predikat pada kedua contoh di atas sama, tetapi memiliki perbedaan dari segi semantik dan sintaksis. Contoh (5) yang merupakan ujaran pasif langsung, Sementara contoh (6) merupakan contoh ujaran pasif tak langsung, Jenis pasif tidak langsung ini tidak memiliki ujaran aktif yang berkoresponden.

Lebih jauh lagi, Heo (2004 : 83) mengklasifikasikan kedua jenis ujaran pasif ini masing-masing menjadi dua subkategori. Berdasarkan jenis subjeknya, pasif langsung dibagi menjadi pasif animate dan pasif inanimate. Sementara itu, pasif tak langsung dibagi menjadi dua yakni pasif possessive (所有物受身) dan pasif non-possesive（非所有物 受身）.Pasif animate adalah jenis pasif di mana subjeknya merupakan mahluk bernyawa yang dapat memiliki perasaan terhadap peristiwa 
yang menimpanya. Sebaliknya, pasif inanimate adalah jenis pasif yang subjeknya merupakan benda tak bernyawa yang tak dapat memiliki rasa terhadap peristiwa yang dialaminya. Kedua jenis pasif ini sendiri dibagi menjadi 4 subkategori lagi. Pertama, pasif animate dibagi menjadi dua, yakni yang subjek maupun pelaku nya (agentif) mahluk bernyawa (pasif tipe ++ ) dan pasif animate yang subjeknya mahluk bernyawa namun nomina yang menempati posisi pelaku (agentif) benda tak bernyawa (pasif tipe + - ). Kedua, pasif inanimate dibagi menjadi pasif (tipe - - ) dan pasif (tipe - +). Sementara itu, karena pasif tak langsung pada dasarnya memiliki subjek animate, maka tidak dapat dibagi menjadi subkategori lebih jauh lagi sebagaimana halnya pasif langsung.

Untuk subkategori pasif tak langsung, pasif possessive adalah pasif yang objek langsung dari verba predikatifnya adalah bagian tubuh ataupun kepunyaan langsung subjek. Sebaliknya, pasif non-possesive adalah pasif tak langsung di mana objek langsung verba predikatif tidak berhubungan dengan subjek atau objek langsung verba predikatifnya tidak ada.

Terkait tuturan pasif dalam basa Sunda, Coolsma (1985:90) menyatakan bahwa secara morfologis, ujaran pasif dalam bahasa Sunda bisa dikategorikan menjadi dua jenis, yaitu pasif pertama dan pasif kedua. Pasif prtama adalah jenis panis yang dibentuk dari verba predikatif dari golongan kata kerja elas satu sampai dengan kelas lima yang diimbuhi dengan awalan $\lceil\mathrm{di}-\lrcorner$. Sedangkan pasif kedua adalah jenis pasif yang dibentuk dari verba predikatif dari golongan kata kerja kelas satu sampai dengan kelas tiga yang diimbuhi dengan awalan $\lceil\mathrm{ka}-」$.

Lebih lanjut, S. Coolsma (1985 :115) menyatakan bahwa makna dari masing - masing jenis pasif adalah sebagai berikut. Pasif kesatu menunjukkan makna bahwa sesuatu mengalami sesuatu oleh sebab tertentu, yang meskipun tidak selalu disebutkan selalu dimengerti. Berbeda dengan pasif pertama, pasif kedua menunjukkan makna bahwa sesuatu telah tertimpakan pada seseorang atau sesuatu tak tergantung pada keinginan melakukannya atau bertentangan dengan keinginannya, misalnya karena tidak sengaja atau sebagai akibat keadaan.

Dengan menggunakan pendekatan klasifikasi yang sama dengan bahasa Jepang, penulis mengklasifikasikan pasif bahasa Sunda berdasarkan 
jenis kebernyawaan (animacy) nomina yang menduduki posisi subjek dalam kalimatnya seperti tabel berikut ini.

Tabel 1. Klasifikasi pasif dalam bahasa Sunda

\begin{tabular}{|c|c|c|}
\hline \multirow{4}{*}{$\begin{array}{c}\text { Pasif kesatu } \\
\text { Pasif Langsung }\end{array}$} & \multirow[t]{2}{*}{ Pasif animate } & Tipe ++ \\
\hline & & Tipe + - \\
\hline & \multirow{2}{*}{ Pasif inanimate } & Tipe - - \\
\hline & & Tipe - + \\
\hline \multirow{5}{*}{$\begin{array}{c}\text { Pasif kedua } \\
\text { Pasif tak langsung }\end{array}$} & \multirow[t]{2}{*}{ Pasif animate } & Tipe ++ \\
\hline & & Tipe + - \\
\hline & \multirow[t]{2}{*}{ Pasif inanimate } & Tipe -- \\
\hline & & Tipe - + \\
\hline & \multicolumn{2}{|c|}{ Pasif non-possesive } \\
\hline
\end{tabular}

Melalui penelitian ini penulis menemukan empat jenis makna dan fungsi konstruksi [ka-verba] dalam bahasa Sunda yang memiliki kemiripan makna dengan konstruksi [-rareru] dalam bahasa Jepang. Pertama adalah yang berfungsi sebagai tuturan untuk mengungkapkan non-volitional passive. Kedua yaitu konstruksi [ka-verba] yang untuk mengungkapkan aspek perfektif atau lebih tepatnya keberlanjutan hasil dari sebuah peristiwa. Ketiga adalah konstruksi [ka-verba] sebagai spontaneus clause atau dalam bahasa Jepang lebih dikenal sebagai jihatsubun (自発 文)、yang digunakan untuk mengungkapkan bahwa peristiwa tersebut terjadi dengan sendirinya atau spontan. Terakhir adalah konstruksi [kaverba] sebagai potential clause atau bentuk dapat yang dalam istilah bahasa Jepang dikenal dengan istilah kanoubun (可能文).

Melalui analisis kontrastif, penulis menemukan bahwa konstruksi [ka-verba] dan konstruksi [-rareru] dalam bahasa Jepang memiliki makna dan fungsi yang sama terutama sebagai pembentuk kalimat spontan (jihatsubun) dan kalimat potensial (kanoubun). Hal ini bisa kita lihat dari perbandingan berikut ini :

\begin{tabular}{|l|l|l|l|}
\hline & 自発用法「ka-動詞」構文 & $\begin{array}{l}\text { 日本語の「〜（ } \\
\text { ら）れる」 }\end{array}$ \\
\hline
\end{tabular}




\begin{tabular}{|c|c|c|c|}
\hline (7) & $\begin{array}{l}\text { Karasa sedih lamun emut ka wanoja } \\
\text { ka-感じる 悲しい もし 覚える に 女性 } \\
\text { 女性のことを思い出すと悲しく感じら } \\
\text { れる。 }\end{array}$ & $\Leftrightarrow$ & $\begin{array}{l}\text { 女性のことを思 } \\
\text { い出すと悲しく } \\
\text { 感じられる。 }\end{array}$ \\
\hline (8) & $\begin{array}{l}\text { Sok kagagas pangalaman anu baheula. } \\
\text { 擬熊語 ka-思い出させる 経験 関係代名詞 } \\
\text { 昔 } \\
\text { 昔の経験が思い出される。 }\end{array}$ & $\Leftrightarrow$ & $\begin{array}{l}\text { 昔の経験が思い } \\
\text { 出される。 }\end{array}$ \\
\hline (9) & $\begin{array}{l}\text { Hawar-hawar kadenge sora adzan } \\
\text { 擬態語 ka-聞< 声 アザン } \\
\text { 䞦くからお祈りの呼びかけの声が聞こ } \\
\text { える。 }\end{array}$ & $\Leftrightarrow$ & $\begin{array}{l}\text { 遠くからお祈り } \\
\text { の呼びかけの声 } \\
\text { が聞こえる。 }\end{array}$ \\
\hline (10) & $\begin{array}{l}\text { 対応する自発用法「ka-動詞」構文が } \\
\text { ない }\end{array}$ & $\Leftrightarrow$ & $\begin{array}{l}\text { 私には佐藤が犯 } \\
\text { 人だと思われ } \\
\text { る。 } \\
\end{array}$ \\
\hline \multirow[t]{2}{*}{ (11) } & $\begin{array}{l}\text { 対応する自発用法「ka-動詞」構文が } \\
\text { ないが以下の表現に言い換えることが } \\
\text { できる } \\
\text { Lamun ninggali foto itu, sok jadi } \\
\text { もし 見る 写真 その 擬態語 なる } \\
\text { hayang seuri. } \\
\text { 〜したい 笑う } \\
\text { その写真を見ると、（自然に）笑い } \\
\text { たくなる。 }\end{array}$ & $\Leftrightarrow$ & $\begin{array}{l}\text { あの写真を見る } \\
\text { と、笑えてしょ } \\
\text { うがない。 }\end{array}$ \\
\hline & 可能用法「ka-動詞」構文 & & $\begin{array}{l}\text { 日本語の「〜（ } \\
\text { ら）れる」 } \\
\end{array}$ \\
\hline (12) & $\begin{array}{l}\text { Tulisan leutik oge kabaca ari } \\
\text { 書いたもの 小さい も ka-読む なら } \\
\text { make kacamata mah. } \\
\text { 使う めがね } \\
\text { 小さく書いた文字でもめがねを使うと } \\
\text { 読める。 }\end{array}$ & $\Leftrightarrow$ & $\begin{array}{l}\text { 小さく書いた文 } \\
\text { 字でもがねを } \\
\text { 使うと読める。 }\end{array}$ \\
\hline
\end{tabular}




\begin{tabular}{|l|l|l|l|}
\hline (13) & $\begin{array}{l}\text { Ti imah ka sakola bisa leumpang. } \\
\text { から 家へ 学校 できる 歩く } \\
\text { 家から学校までは歩ける。 }\end{array}$ & $\Leftrightarrow$ & $\begin{array}{l}\text { は歩ける。家まで } \\
\text { 学 }\end{array}$ \\
\hline
\end{tabular}

Dari data di atas kita bisa melihat bahwa kalimat (7), (8), dan juga (9) secara struktur dan makna memiliki persamaan dengan konstruksi [-rareru] dalam Bahasa Jepang. Keduanya merupakan konstruksi kalimat spontan (jihatsubun) dan menunjukkan makna sebuah perbuatan terjadi dengan sendirinya tanpa adanya kehendak dari pelaku perbuatan yang menenpati posisi subjek dalam kalimat. Akan tetapi, kalimat (10) dan (11) dalam Bahasa Jepang tidak dapat diungkapkan dalam basa Sunda dengan menggunakan konstruksi [ka-verba] walaupun memiliki makna yang serupa dengan tiga kalimat di atasnya. Hal ini dikarenakan jumlah verba persepsional dalam basa Sunda yang dapat bergabung dengan awalan [ka] untuk membentuk makna jihatsu sangat terbatas dibandingkan dengan verba dalam Bahasa Jepang yang dapat bergabung dengan [-rareru] untuk membentuk makna serupa. Maka dari itu, kita harus menggunakan konstruksi kalimat yang lain pada saat menyulih kalimat (10) dan (11) disulih ke dalam basa Sunda.

Apabila dilihat dari struktur kalimatnya, tuturan dalam kedua bahasa di atas sama - sama tidak memunculkan pengalam secara eksplisit. Akan tetapi, apabila kita telaah berdasarkan ciri khas struktur kalimat basa Sunda dan bahasa Jepang, kita akan dapat memahami bahwa pengalam yang merupakan pronomina persona pertama sekaligus penutur dalam bahasa Jepang akan menduduki posisi subjek sementara dalam kalimat basa sunda akan menduduki posisi pelaku perbuatan yang ditandai dengan kata depan ku "oleh" seperti halnya konstruksi tuturan pasif lainnya.

Adapun untuk konstruksi [ka-verba] yang berfungsi sebagai potential clause atau kanoubun, kita dapat melihat bahwa yang memiliki persamaan dengan konstruksi [-rareru] hanyalah kalimat (12). Secara morfologis terdapat perbedaan mendasar antara bentuk potensial \{ka-verba\} dengan [-rareru] terkait degan verba dasar yang menjadi predikatnya. Verba predikat konstruksi [ $\mathrm{ka}$ - verba] jenis ini hanya dapat dibentuk dari verba dasar transitif berargumen dua atau lebih dikenal dengan sebutan nikoudoushi (二項動詞) dalam bahasa Jepang (kalimat 12), sedangkan bentuk potensial [-rareru] dalam bahasa Jepang dapat dibentuk baik dari verba dasar transitif maupun intransitif. Hal ini juga lah yang menyebabkan 
kalimat (13) dalam bahasa Jepang tidak dapat disulih ke dalam konstruksi [ka-verba] dalam basa Sunda dan harus disulih ke dalam bentuk yang lain yaitu konstruksi kalimat aktif.

\section{Simpulan}

Berdasarkan hasil analisis, kita dapat menyimpulkan bahwa konstruksi [ka-verba] merupakan memiliki fungsi dasar untuk menunjukkan pasif tak berkehendak (non volitional passive) yang dalam perjalanannya berkembang menjadi konstruksi dengan beberapa fungsi dengan makna yang berbeda yaitu menujukkan aspek perfektif berkelanjutannya hasil sebuah perbuatan, kalimat spontan (jihatsu), dan kalimat potensial (kanoubun) sambil mempertahankan ciri khas konstruksi asalnya. Melalui analisis kontrastif dengan konstruksi [-rareru] bahasa Jepang, kita dapat juga menarik kesimpulan bahwa sebagian konstruksi [ka-verba] dalam bahasa Jepang khususnya yang memiliki fungsi sebagai jihatsubun dan kanoubun dapat saling sulih dengan konstruksi [-rareru] yang bermakna serupa terlepas dari perbedaan karakteristik secara morfologis terkait dengan jenis verba dasar predikat serta posisi sintataksis baik pelaku perbuatan ataupun pengalamnya.

\section{Daftar Pustaka}

Coolsma, S.(1985) Tata Bahasa Sunda. Terjemahan Husein

Widjadjakusumah dan Yus Rusyana. Jakarta: Djambatan

Djajasudarma, T.F. (1980) Tata Basa Sunda.Bandung: Rahmat Cijulang.

Karna Yudibrata (1989) Bagbagan Makena Basa Sunda. Bandung: Rahmat

Cijulang.

Heo MyonJya (2004), Nihongo no Ukemi to Kankokugo no Ukemibun no

Taisho Kenkyuu, Hitsuji Shobo

Kats, J\&M.Soeriadiradja (1982) Tata Bahasa dan Ungkapan Bahasa

Sunda. Terjemahan Ayatroaedi. Jakarta: Djambatan.

R.H. Robins (1970) Diversions of Bloomsbury North-Holland Publishing

Company

R.A Danadibrata(2006) Kamus Basa Sunda. Bandung: PT Kiblat Buku

Utama 
Takami Kenichi (1997), Kinouteki Tougoron, Kuroshio Shuppan

TeramuraHideo (1982), Gengo no Taishoteki Bunseki to Kijutsu no

Houhou, Kouza Nihongogaku 10, Meijishuin 